Revue bibliographique pour le domaine irano-aryen

\title{
Robert Rollinger, Josef Wiesehöfer. Königlicher Haushalt, Residenz und Hof : Der Persische König und sein Palast
}

\section{Astrid Nunn}

\section{(2) OpenEdition \\ 1 Journals}

\section{Édition électronique}

URL : http://journals.openedition.org/abstractairanica/40409

DOI : 10.4000/abstractairanica.40409

ISSN : 1961-960X

Éditeur :

CNRS (UMR 7528 Mondes iraniens et indiens), Éditions de l'IFRI

\section{Édition imprimée}

Date de publication : 1 décembre 2013

ISSN : 0240-8910

Référence électronique

Astrid Nunn, «Robert Rollinger, Josef Wiesehöfer. Königlicher Haushalt, Residenz und Hof : Der Persische König und sein Palast », Abstracta Iranica [En ligne], Volume 32-33 | 2013, document 113, mis en ligne le 01 juillet 2016, consulté le 27 septembre 2020. URL : http://journals.openedition.org/ abstractairanica/40409; DOI : https://doi.org/10.4000/abstractairanica.40409

Ce document a été généré automatiquement le 27 septembre 2020.

Tous droits réservés 


\title{
Robert Rollinger, Josef Wiesehöfer. Königlicher Haushalt, Residenz und Hof : Der Persische König und sein Palast
}

\author{
Astrid Nunn
}

\section{RÉFÉRENCE}

Robert Rollinger, Josef Wiesehöfer. « Königlicher Haushalt, Residenz und Hof : Der Persische König und sein Palast », in : Christiane Karrer-Grube et al., Hg., Sprachen Bilder - Klänge. Dimensionen der Theologie im Alten Testament und in seinem Umfeld.

Festschrift für Rüdiger Bartelmus zu seinem 65. Geburtstag. Münster, Ugarit-Verlag, 2009, p. 213-225. (AOAT 359)

En partant d'une description de la cour achéménide faite dans le traité pseudoaristotélicien de mundo les AA. étudient le rapport du Grand Roi à son palais. Le fait de construire est un acte symbolique et représentatif. Mais le "palais» est aussi le «oikos", la "maisonnée» du roi, qui englobe la famille, les domestiques et les fonctionnaires. Dans ce contexte, les AA. passent en revue le mot «apadana » et la relation du Grand Roi avec le peuple, tout en déconstruisant les préjugés dont nous avons hérité des Grecs. 


\section{AUTEURS}

\section{ASTRID NUNN}

Université de Munich 